\title{
Met meer menselijke maat naar een toekomstbestendige zorg voor chronisch zieken
}

Citation for published version (APA):

van Eijk, J. T. M. (2010). Met meer menselijke maat naar een toekomstbestendige zorg voor chronisch zieken: Afscheidsrede van Prof. dr. Jacques Th.M. van Eijk. (1 ed.) Universiteit Maastricht. https://doi.org/10.26481/spe.20101029je

Document status and date:

Published: 29/10/2010

DOI:

10.26481/spe.20101029je

Document Version:

Publisher's PDF, also known as Version of record

\section{Please check the document version of this publication:}

- A submitted manuscript is the version of the article upon submission and before peer-review. There can be important differences between the submitted version and the official published version of record.

People interested in the research are advised to contact the author for the final version of the publication, or visit the DOI to the publisher's website.

- The final author version and the galley proof are versions of the publication after peer review.

- The final published version features the final layout of the paper including the volume, issue and page numbers.

Link to publication

\footnotetext{
General rights rights.

- You may freely distribute the URL identifying the publication in the public portal. please follow below link for the End User Agreement:

www.umlib.nl/taverne-license

Take down policy

If you believe that this document breaches copyright please contact us at:

repository@maastrichtuniversity.nl

providing details and we will investigate your claim.
}

Copyright and moral rights for the publications made accessible in the public portal are retained by the authors and/or other copyright owners and it is a condition of accessing publications that users recognise and abide by the legal requirements associated with these

- Users may download and print one copy of any publication from the public portal for the purpose of private study or research.

- You may not further distribute the material or use it for any profit-making activity or commercial gain

If the publication is distributed under the terms of Article $25 \mathrm{fa}$ of the Dutch Copyright Act, indicated by the "Taverne" license above, 
Met meer menselijke maat naar een toekomstbestendige zorg voor chronisch zieken 


\section{Colofon}

Ontwerp en print: Océ Business Services, Maastricht

ISBN:

NUR:

Alle rechten voorbehouden. Niets uit deze uitgave mag worden verveelvoudigd, opgeslagen in een geautomatiseerd gegevensbestand of openbaar gemaakt worden, zonder voorafgaande schriftelijke toestemming van de auteur of uitgever. 


\section{Met meer menselijke maat naar een toekomstbestendige zorg voor chronisch zieken}

Afscheidsrede

Maastricht, 29 oktober 2010

Door Prof. dr. Jacques Th.M. van Eijk 
Within Western Europe in particular, there is a tendency to consider unavoidable human suffering,like the loss of dear ones, as a disease episode and to diagnose this as mental illness because of the current system of counting symptoms. This is the medicalisation of stress and sadness. This is reinforced by pressures to prescribe medicines to people who go through a period of stress or mourning: these experiences are often labelled as "treatment required", undermining people's abilities to cope with normal stresses of life. The opposing trend is that mental health problems often present through physical symptoms and are not recognized, neither by the person affected nor by the care provider whose assistance is asked. Also, mental health problems are often denied because of the stigma attached to mental illness, especially among the lower socio-economic groups.

Aarendonk D. Mental Health in Europe, role and contribution of Primary Care. Utrecht: European Forum for Primary Care, 2006. 
Mijnheer de Rector, Dames en Heren,

\section{Introductie}

Begin jaren negentig startte mijn zoon zijn studie geneeskunde. De decaan van de faculteit geneeskunde nodigde de ouders van alle eerste jaar geneeskunde studenten uit voor een introductie over de opleiding aan de betreffende faculteit. Dat was een uitstekend initiatief. Uiteraard heb ik niet meer het hele verhaal op mijn netvlies, maar één beeld is wel heel duidelijk blijven hangen. Tot mijn verrassing, maar niet zonder zijn trots, vertelde de decaan dat aan de betreffende faculteit de preklinische vakken de belangrijkste basis voor de medische opleiding vormden. De aandacht voor die vakken was van eminent belang om een goede arts te worden. Natuurlijk was het ook erg belangrijk dat de toekomstige arts de nodige communicatieve vaardigheden zou verwerven, maar die konden uiteraard ook, of misschien nog wel beter, in het studentenleven aangeleerd worden, want het studentenleven tierde in de betreffende stad welig. Aankomende studenten werd dan ook dringend geadviseerd om lid te worden van een van de plaatselijke studentenverenigingen, zodat in de opleiding alle tijd kon worden ingeruimd voor de basisvakken.

Ik kan u verzekeren dat het met de communicatieve vaardigheden van mijn zoon is het goed gekomen. Maar het standpunt van de decaan was uiteraard destijds al achterhaald. Toch zien we pas in de raamplannen vanaf 1994 tot 2009 dat de verschuivingen in het morbiditeitpatroon (van relatief veel acute ziekten naar relatief veel chronische ziekten) ook tot veranderingen in de beoogde eindtermen van de geneeskunde opleiding hebben geleid ${ }^{1,2}$. Er is meer aandacht voor chronische degeneratieve aandoeningen, er is eerder in de opleiding contact met patiënten en ook de arts als persoon, met zijn communicatieve vaardigheden, staat nadrukkelijker op de voorgrond dan voorheen. Zo vermeldt het raamplan Geneeskunde 2009 dat "de juist afgestudeerde arts kennis heeft van en inzicht in de mechanismen die ten grondslag liggen aan het ontstaan en in stand houden van psychische klachten en aandoeningen" (hfst 4). Of: "De juist afgestudeerde arts heeft kennis van en inzicht in de mechanismen die ten grondslag liggen aan het ontstaan en in stand houden van lichamelijk onverklaarde klachten (zoals angst en depressie; hfst 5). Of: "De juist afgestudeerde arts heeft kennis van en inzicht in de normale psychologische en sociale eigenschappen van 
de mens" (hfst 7). Tevens wordt de arts geacht inzicht te hebben in de gevolgen van het chronisch ziek zijn voor het dagelijks functioneren, aldus het raamplan.

De eindtermen zijn duidelijk. Toch is er een discrepantie tussen het beeld van het ideaal opgeleide arts en de praktijk van het onderwijs en de zorg. Het College voor beroepen in de gezondheidszorg (CBOG) propageert zelfs een paradigma shift ${ }^{3}$. Er is een roep om meer eigen regievoering van patiënten, betere benutting van restcapaciteit, grotere eigen verantwoordelijkheid, vraaggerichte zorg en het centraal stellen van de patiënt. Niet alleen in de opleidingen (beroepsopleidingen incluis), ook in de praktijk van de zorg wringt het en het gaat verder wringen met de te verwachten toename van het aantal chronisch zieken. Een groot deel van de chronisch zieken krijgt tegen de richtlijnen in inactiverende psychofarmaca voorgeschreven 4 . De opvang van deze toename vormt de grote uitdaging voor de toekomst. Als we de huidige zorg op dezelfde manier willen blijven leveren, zullen alle schoolverlaters de komende periode in de gezondheidszorg moeten gaan werken4. Alle goede bedoelingen uit het raamplan ten spijt, blijft het dus de vraag in hoeverre de opleiding en de zorg op dit moment voldoende op deze uitdaging worden voorbereid. Deze tegenstelling tussen ideaal en werkelijkheid in de zorg voor chronisch zieken fascineert mij. Graag wil ik u meenemen op mijn zoektocht naar mogelijke oorzaken van deze discrepantie.

Ik doe dat aan de hand van de volgende onderwerpen:

1. Eerst bekijk ik het functioneren van chronisch zieken in hun omgeving vanuit de optiek dat mensen leven in sociale netwerken.

2. Vervolgens zal ik nagaan wat van hulpverleners en huisartsen wordt verwacht ten aanzien van de hulp aan chronisch zieken zoals dat is vastgelegd in de richtlijnen van het Nederlands Huisartsen Genootschap en andere richtlijnen.

3. Daarna maak ik een ommetje door kort de ontwikkelingen in de psychiatrie van de afgelopen decennia te bekijken en na te gaan in hoeverre dit de aard en de diagnostiek van psychische problemen heeft beïnvloed.

4. Vervolgens ga ik in op de invloed van de psychiatrie op de zorg voor psychische problemen in de eerste lijn. 
5. Wellicht heeft ook de marktwerking invloed op hoe de zorg voor chronisch zieken eruit ziet. Ik bekijk dat vanuit de optiek van het onderwijs en de zorg.

6. Ten slotte kom ik dan op geleide van mijn analyse tot een aanzet voor een mogelijke oplossingsrichting voor een toekomstbestendige chronische zorg.

\section{Het dagelijks functioneren van chronisch zieken}

\section{Netwerken}

Mensen zijn, ziek of niet, in het dagelijks leven op elkaar aangewezen. Mensen leven in sociale netwerken waarin zij van elkaar afhankelijk zijn. De een is wat meer aangewezen op anderen dan de ander en dat bepaalt ook hoe invloedrijk iemand is binnen een netwerk, maar invloedrijk of niet, zeker is dat men niet zonder elkaar kan. Normaal gesproken is het netwerk in een zekere balans. Dat kan veranderen als er in de wederzijdse afhankelijkheden belangrijke wijzigingen optreden, bijvoorbeeld als een invloedrijk persoon het netwerk om een of andere reden verlaat of als iemands afhankelijkheid van anderen uit het netwerk toeneemt, zoals iemand die door ziekte niet meer in staat is binnen het netwerk de gebruikelijke rol te spelen. De kern van de sociale netwerkconfiguratie is het primaire netwerk, het gezin, het samenlevingsverband waar voorzien wordt in de meest primaire levensbehoeften. Er zijn vanuit de psychologie en sociologie voldoende aanwijzingen dat het primaire leefmilieu een belangrijke rol speelt bij de ontwikkeling van vaardigheden om met ingrijpende levensgebeurtenissen, zoals ziekte, om te gaan. Andere meer secundaire netwerken worden gevormd met collega's, vrienden, buren etc. Een van de kenmerken die in tijden van ziekte of andere ingrijpende levensgebeurtenissen van belang zijn, is de sociale steun die iemand dan ondervindt5. Die bepaalt mede of en hoe succesvol iemand met ingrijpende veranderingen omgaat. Het maakt daarbij uit of het gaat om instrumentele hulp (hulp bij boodschappen, huishouden etc.) dan wel emotionele steun (hulp bij het verwerken van emoties). Wetenschappelijk is voldoende vastgesteld dat sociale steun bijdraagt aan de gezondheid, zowel direct als indirect (bufferhypothese: support mitigeert het effect van stress op ziekte) ${ }^{6}$. De afgelopen decennia zijn netwerken steeds dynamischer en losser geworden waardoor mensen steeds meer moesten terugvallen op het primaire netwerk. 


\section{Het ontstaan van chronische ziekte: verafhankelijking}

Als bekend wordt dat iemand een chronische ziekte heeft, zijn er vanaf dat moment (meestal de rest van het leven) voortdurende aanpassingen noodzakelijk, samenhangend met het beloop van de ziekte. De eerste belangrijke verandering is de wijziging van het zelfbeeld. De ziekte brengt beperkingen met zich mee die het rolpatroon van de chronisch zieke ingrijpend kunnen veranderen. De chronisch zieke zal ervaren dat hij/zij door die beperkingen niet meer in staat is de rollen te vervullen zoals voorheen (werk, hobby's, gezin etc). Meer dan het hebben van de chronische ziekte zelf, zijn vooral zorgen om de beperkingen van de ziekte en de gevolgen daarvan voor deelname aan netwerken, voor patiënten het belangrijkste aandachtspunt. Er is onzekerheid over hoe het verder gaat en er is onzekerheid over welke rollen nog wel/niet kunnen worden gespeeld. Uiteraard gaan deze veranderingen ook niet voorbij aan de omgeving. Die kan daar weer op allerlei verschillende manieren op reageren: bezorgd, ondersteunend etc. Het gevolg is dat er voortdurende aanpassingen moeten plaats vinden in de relevante rolverwachtingen. Chronisch zieken worden geleidelijk aan steeds meer afhankelijk van mensen uit hun omgeving en ook van professionele zorg. Hoe de chronisch zieke hiermee omgaat en uiteraard ook hoe de omgeving i.c. de hulpverlening hierop reageert, is van groot belang voor de wijze waarop de noodzakelijke aanpassingen aan de nieuwe situatie plaats vinden. Essentieel is dat zoveel mogelijk de restcapaciteit benut wordt. Daaraan ontleent de chronisch zieke zelfrespect en gevoel van autonomie en dat vormt, binnen de gegeven mogelijkheden, de belangrijkste trigger voor sociale participatie in netwerken.

\section{De rol van de chronisch zieke zelf}

Veranderingen in de gezondheidstoestand maken dus herziening van het zelfbeeld noodzakelijk. Van belang hierbij is dat dit herziene zelfbeeld realistisch is en uitgaat van de nog aanwezige mogelijkheden tot sociale participatie. Dat deze aanpassing niet altijd naar wens verloopt, blijkt uit het relatief hoge percentage chronisch zieken met angstklachten, stemmingsproblemen en sterke gevoelens van onbehagen. Alleen al voor depressie bedraagt de prevalentie $20-25 \%$. Nu is het voor de hand liggend dat fysieke achteruitgang op gezette tijden tot onzekerheid over de toekomst, somberheid, angstige gedachten of spanning leidt. Deze gevoelens horen bij een realistisch zelfbeeld. Er is echter ook een minder realistische reactie mogelijk. In dat geval treedt er vernauwing van het zelfbeeld op, waardoor bestaande restmogelijkheden onvoldoende benut worden. Het resultaat hiervan is dat het aantal gedragsalternatieven 
beperkt wordt en erger: dat de mogelijkheid tot exploratie van alternatieven (die gegeven de veranderde gezondheidstoestand nodig is) wordt vermeden. Dat hierdoor het gevoel van eigenwaarde verder wordt ondermijnd, lijdt geen twijfel: De chronisch zieke komt in een neerwaartse spiraal ${ }^{8}$. Uiteraard heeft de omgeving op dit proces grote invloed.

\section{De rol van de omgeving}

Het zelfbeeld van de chronisch zieke staat niet op zichzelf. Het staat in relatie tot de zelfomschrijvingen van mensen uit de omgeving. lemand met een zelfbeeld van sterkte bevindt zich in een dominante positie ten opzichte van iemand met een zelfbeeld van zwakte. In geval van ziekte verandert de zelfomschrijving van de zieke en verandert daarmee dus ook de onderlinge relatie. Zo bestaat er in het primaire leefmilieu een systeem van onderlinge relaties en hetzelfde geldt voor de meer secundaire netwerken, als de arbeid etc. De wederkerigheid van de zelfomschrijvingen weerspiegelt een patroon van rechten en plichten dat in tijden van verandering uiteraard onder druk komt te staan. Er moet een nieuw evenwicht komen in de onderlinge verhoudingen. Vooral indien de onderlinge verhoudingen erg flexibel zijn, is het netwerk in staat tot adaptatie en zal er eerder een aan de nieuwe situatie aangepaste balans ontstaan. Omgekeerd zal een netwerk met starre verhoudingen veel moeizamer tot een nieuwe balans komen en gaat het bereiken daarvan met veel meer pijn en moeite gepaard. In een relatie waarin de zieke een dominante positie innam vóór de ziekte, moet de ander taken van de chronisch zieke overnemen, dan wel deze daarbij ondersteunen. Dat geldt niet alleen voor instrumentele taken zoals het doen van boodschappen, maar meer nog voor emotionele steun bij het verdriet die voor het vinden van de nieuwe balans van cruciale betekenis blijkt9,10.

\section{De rol van de hulpverlening}

Ook de wijze waarop hulpverleners ingaan op de gevolgen van de ziekte voor het dagelijks leven van patiënten is van cruciale betekenis voor hun zelfbeeld. Een arts die uitsluitend het somatische spoor bewandelt, heeft maar weinig oog voor de beperkingen en de dagelijkse problemen die patiënten ervaren als gevolg daarvan. Zo creëert exclusieve aandacht voor de longfunctie en rookgedrag van een patiënt met COPD bij patiënten het beeld dat de arts er uitsluitend is voor de somatiek. Dit roept bij patiënten het beeld op dat er dus ook primair somatisch iets aan de hand is. Dus vooral lichamelijke klachten in verband met de ziekte 
legitimeren het artsbezoek. De zorg van de patiënt is echter niet zozeer diens longfunctie, maar vooral dat hij binnen de kortste keren buiten adem is en daarom niet aan het sociale leven kan deelnemen zoals hij/ zij dat wenst: de patiënt maakt zich druk om het feit dat hij de trap niet meer opkomt en niet om de slechte longfunctie. Uit onverwachte hoek krijgt de opvatting dat de hulpverlener grote invloed uitoefent op het hulpverleningsproces en ook op de uitkomst daarvan, de laatste jaren steun. Neurobiologen tonen aan de hand van placebo effecten aan welke grote invloed een arts heeft op het therapeutisch resultaat, met name bij patiënten met problemen waarbij emoties zoals angst, somberheid of onzekerheid en pijn een rol spelen ${ }^{11}$. En in recent onderzoek tonen Nederlandse onderzoekers aan hoe sterk en eenduidig het effect van een warme empathische communicatie stijl van artsen is op angst, gevoelens en pijn. Allemaal sterke aanwijzingen dat hulpverleners in het belang van de patiënt (en het behandelingsresultaat) verder dienen te gaan dan de aanpak van het fysieke probleem en meer dienen aan te sluiten bij datgene wat de patiënt bezig houdt ${ }^{12}$.

Inmiddels weten we dat aandacht voor mentale problemen bij chronisch zieken geen overdreven luxe is. Psychische problemen zoals angst en depressie komen bij chronisch zieken relatief vaak voor. Het signaleren van deze problemen en vervolgens aanpakken daarvan, is uit oogpunt van integrale zorg op zich zelf al van belang, maar de afgelopen decennia is steeds meer bewijs aangedragen voor de wisselwerking en samenhang tussen psychische en lichamelijke problemen. Hierbij blijkt een ontregeld immunologisch systeem te intermediëren tussen lichaam en geest. lemand met een depressie heeft een grotere kans op hart en vaatziekten en iemand met een hartziekte heeft een grotere kans op depressie ${ }^{13}$. Een ander bekend mechanisme is dat mensen die angstig of depressief en dus eerder bij de pakken neerzitten, ook minder geneigd zijn leefregels en het medisch regiem te volgen ${ }^{14}$. Vanuit professioneel gezichtspunt is het dus van groot belang dat hulpverleners ingaan op de problemen waarmee chronisch zieken in het dagelijks leven worstelen. Dat leidt niet alleen tot betere maar ook tot efficiëntere zorg. 


\section{Wat schrijven de richtlijnen voor de zorg voor chronisch zieken voor?}

Om een beeld te krijgen hoe de eerste lijn zorg voor chronisch zieken eruit ziet, heb ik een kijkje genomen in de keuken van de eerste lijn om aan de hand van richtlijnen en standaarden te bekijken in hoeverre aandacht voor de niet fysieke aspecten van het leven met een chronisch ziekte ook terugkomt in de richtlijnen.

\section{NHG richtlijnen}

Kijken we naar de NHG standaarden, dan vind ik bij de standaard longemphyseem de volgende passage:

"Bij psychosociale problemen geeft de huisarts (emotionele) ondersteuning en adviezen. Bij ernstiger problematiek, zoals een angststoornis of depressie, stelt de huisarts zelf een behandeling in of verwijst de patiënt hiervoor naar een psycholoog of psychiater ${ }^{15}$." Hier vinden we dus aanknopingspunten maar erg concreet zijn die niet. Wat zijn psychosociale problemen en ondersteuning en adviezen? Wanneer moet je aan een angststoornis of depressie denken? Feitelijk moet je daarvoor naar de standaarden depressie en angststoornis, maar die zijn met name opgezet vanuit het perspectief van iemand die met angst- of depressieklachten bij de huisarts komt.

In de standaard Artritis is geen verwijzing te vinden naar de niet fysieke aspecten. Dat is opvallend, want mensen met deze problemen zijn vaak somber vanwege de pijnklachten en de daaruit voortvloeiende beperkingen ${ }^{16}$.

In de standaard astma bij volwassenen wordt onder het hoofdje voorlichting en begeleiding voorgesteld om te vragen naar: "De manier waarop de patiënt met zijn aandoening omgaat. Bespreek belemmeringen in het functioneren door angst en kortademigheid of schaamte voor het gebruik van medicijnen in gezelschap ${ }^{17}$ ". Deze aanwijzing is al wat concreter doordat wordt voorgesteld om naar een concrete belemmering te vragen in het functioneren. Deze richtlijn komt heel dichtbij het dagelijks functioneren en biedt goede aanknopingspunten om verder na te gaan hoe groot de ziektelast voor patiënten is.

De standaard diabetes bevat een richtlijn voor educatie maar deze is uitsluitend gericht op leefregels. Verder ontbreekt een verwijzing naar problemen met het dagelijks functioneren ${ }^{18}$. 
In de standaard beleid na een infarct is in de anamnese in de stabiele fase een richtlijn opgenomen om jaarlijks te vragen naar psychosociale problemen, angst, depressieve klachten, en de gevolgen hiervan voor het dagelijks functioneren. Ook hier wordt doorverwezen naar de NHG-Standaarden Angststoornissen en Depressie. Bij revalidatie na een infarct lezen we: "In de regel begint de patiënt enkele weken na het infarct met hartrevalidatie en volgt deze tweemaal per week een programma gedurende 2 tot 3 maanden. Naast de oefentherapie wordt daarbij aandacht besteed aan de coping mechanismen van de patiënt, zoals de manier waarop deze met angst omgaat, met het doel de belastbaarheid te vergroten, zowel in de thuis- en werksituatie als bij het opnieuw opnemen van hobby's of sport ${ }^{19}$.

De standaard CVA: "Het is belangrijk om in elke fase systematisch te vragen naar problemen met het fysieke, psychische en sociale functioneren van de patiënt. Als patiënten en centrale verzorgers zich slecht geïnformeerd voelen, blijven zij hierover met vragen zitten. Uit onderzoek op drie verschillende momenten (na twee weken, een halfjaar en twee jaar) blijkt dat angst voor een recidief op elk moment speelt. Vragen over psychologische gevolgen nemen toe na een half jaar en twee jaar. Na twee jaar stellen patiënten en centrale verzorgers vragen over concentratie- en geheugenproblemen, vermoeidheid, depressie en frustratie en kunnen ze nog onzeker zijn over kansen op herstel ${ }^{20}$.

In deze standaard wordt dus geadviseerd om in elke fase systematisch na te gaan of zich problemen voordoen bij het fysieke, psychische of sociale functioneren van de patiënt. Hoe dat zou moeten wordt niet geconcretiseerd.

Vooral in de standaard CVA, en in mindere mate in de standaard beleid na infarct en astma bij volwassenen, vinden we goede aanzetten om na te gaan hoe het de patiënt en diens omgeving in het dagelijks leven vergaat. Aansluiten bij psychische problemen vereist echter nog een laatste stap, $\mathrm{nl}$ doorvragen naar de in het dagelijks leven ervaren ziektelast en de manier waarop daarmee wordt omgegaan. Objectieve maten zoals de Barthel index zijn daarvoor niet geschikt want die geven een indicatie van de objectieve mogelijkheden van patiënten, maar vragen niet naar de problemen waarop patiënten stuiten in het dagelijks leven en hoe ze die oplossen. Over het algemeen zijn er dus goede, maar onvoldoende specifieke richtlijnen om problemen met het dagelijks functioneren op 
tafel te krijgen en hoe te handelen als er problemen zijn. Overigens is het erg opvallend dat de groepen die de NHG standaarden voorbereiden, tot op heden voor het deel van de ziekte last van de patiënten, inbreng van patiënten zijde node moeten missen. Ook over een mogelijke rol voor de mantelzorgers laten de standaarden zich niet uit.

\section{Zorgstandaarden}

Met het oog op de te verwachten toevloed van chronisch zieken en om de kwaliteit van de zorg voor o.m. chronisch zieken te verbeteren, stelde de vorige minister van VWS een Regieraad Kwaliteit van Zorg in met als taak meer structuur en aansturing te geven bij de ontwikkeling en implementatie van richtlijnen voor zorgverlening. Als gevolg van de marktwerking is immers te verwachten dat alle marktpartijen (beroepsgroepen, zorgverzekeraars, patiëntverenigingen en inspectie) zich met de kwaliteit van de zorg gaan bezig houden. Het moet natuurlijk geen janboel worden doordat iedere marktpartij zijn eigen wensen gaat bepalen. Daarom zijn er inmiddels onder regie van deze raad in aansluiting op de NHG standaarden nu ook zgn. zorgstandaarden in voorbereiding. De voornaamste functie van een zorgstandaard is: "richting geven aan de wijze waarop de zorgvraag van mensen met een chronische aandoening of risico daarop wordt beantwoord (uiteraard in samenhang met de klinische behandelrichtlijnen), zodanig dat zij hun leven met een chronische aandoening als volwaardig burger kunnen inrichten"21. De Nederlandse Diabetes Federatie heeft al in 2007 een zorgstandaard voor diabetes uitgebracht. Maar ook in deze "integrale" standaard is geen gerichte aandacht voor last in het dagelijks leven met het hebben van diabetes en de beoogde rol van hulpverleners daarbij ${ }^{22}$. Wel wordt gemeld dat maatschappelijk werk en de eerste lijnpsycholoog betrokken zijn bij de zorg. Het blijft hier dus bij een aanzet. Verder is recent de Zorgstandaard COPD gepubliceeerd ${ }^{23}$. Deze standaard bevat een aparte paragraaf over psychosociale behandeling en begeleiding. Hierin wordt gepleit voor systematische aandacht van de hulpverlener voor problemen van COPD-patiënten in het dagelijks leven. Dit betreft niet alleen angst en somberheid, maar ook in samenhang daarmee problemen in gezin, werk of sociale contacten. In de standaard wordt gepleit voor een patiëntgerichte benadering met een accent op eigen verantwoordelijkheid van de patiënt. Deze contextgerichte benadering vormt een prima uitgangspunt voor concrete richtlijnen voor signalering en aanpak van problemen in het dagelijks functioneren. Ook de rol van mantelzorg wordt besproken. 


\section{Keten DBC}

De NDF zorgstandaard diabetes beschrijft wat de norm voor adequate behandeling van patiënten met diabetes is, maar blijft onduidelijk over de taakverdeling. Ten behoeve van de noodzakelijke vertaling naar de feitelijke zorg is mede om die reden geëxperimenteerd met een zgn "keten DBC" 24.Dit is eigenlijk een soort functionele omschrijving van het totaal pakket aan te verrichten taken in verband met een chronische ziekte (in dit geval de diabeteszorg) zoals die ook zijn ontwikkeld voor de ziekenhuissector. De prijs van een keten DBC is vrij onderhandelbaar met de zorgverzekeraar. Huisartsen spelen in de zorg voor chronisch zieken uiteraard een belangrijke rol en om die reden zien we vanuit die beroepsgroep vooral de initiatieven tot oprichting van zgn. zorggroepen (vereniging van zorgaanbieders). De zorggroepen fungeren als aannemer die met de betreffende disciplines onderhandelt over de prijzen van deelactiviteiten, zoals de aannemer zelf ook onderhandelt met de zorgverzekeraar over de totaal prijs van een keten DBC. Naast diabetes zijn er nu ook initiatieven op het gebied van longziekten, cardiovasculair risicomanagement en ouderenzorg. Zo'n keten DBC zou dus alle noodzakelijke elementen van goede zorg bevatten, maar bij die van diabetes ontbreekt aandacht voor de ziektelast en de zelfredzaamheid van diabetespatiënten. En dat is eigenlijk ook niet zo verwonderlijk want dit element komt ook niet voor in de NDF standaard, noch in de NHG standaard.

Richtlijnen voor de zorg voor chronisch zieken zijn concreet uitgewerkt voor de somatische aspecten van chronische ziekte, maar meestal onvoldoende concreet gericht op psychische problemen van patiënten die de uitdrukking zijn van de worsteling van patiënten met de beperkingen van hun ziekte. De richtlijnen voor de diagnostiek, behandeling en follow-up van chronische ziekten kunnen hierop overigens eenvoudig worden aangepast, want verschillende standaarden bieden hiervoor concrete aanknopingspunten. Dit geldt m.n. voor de standaarden "beleid na infarct en CVA". Systematische en consequente toespitsing op de gevolgen van de beperkingen van chronische ziekten voor het dagelijks leven, kan ervoor zorgen dat dit element beter wordt geïntegreerd in de standaarden, waardoor het een betere kans krijgt in de reguliere zorg. Patiënten inbreng hierbij zou niet misstaan. Behalve de standaarden zijn ook de NDF standaard en de keten DBC makkelijk op dit punt aan te passen. Een mooi voorbeeld hoe dat zou kunnen wordt gegeevn in de zorgstandaard COPD. Hoewel van diverse kanten een integrale 
benadering van de zorg voor patiënten met een chronische ziekte wordt gepropageerd (Chronic care model), blijkt de praktijk dus tamelijk weerbarstig 25 . Inmiddels komt er ook een duidelijke roep vanuit de samenleving. Met het oog op de toekomst dient het accent van de zorg verlegd te worden van zorg voor de patiënt naar zorg voor zelfredzaamheid ${ }^{26}$.

\section{Ontwikkelingen in de psychiatrie}

In de jaren 70 ontstond er vanuit de wetenschap grote druk op de psychiatrie om zich te bewijzen als wetenschappelijke discipline. Dit vormde een belangrijke aanzet voor het kwantitatieve empirisch onderzoek die het fundament diende te leveren voor evidence based psychiatrie. Mede om die reden zien we eind jaren 70 een diagnostisch classificatie systeem van een compleet andere orde tot stand komen dan daarvoor ${ }^{27,28}$. De eerste Diagnostic Statistical Manual (DSM-I) werd gepubliceerd in 1952. Deze manual was 130 pagina's lang met in totaal 106 psychische stoornissen ${ }^{27}$. In 1974 verschijnt de DSM-II met nu 182 stoornissen. Weliswaar betrof dit een diagnose classificatie maar symptoom diagnostiek ontbrak volledig. Het zal wel geen toeval zijn geweest dat in die periode veel wetenschappelijke kritiek werd geleverd op de conventionele psychiatrie. De DSM-II was subjectief, onwetenschappelijk (onbetrouwbaar en invalide) en veel te ambitieus in de veelal speculatieve verklaringen van psychische problemen die zich aan empirische verificatie onttrokken. Tegelijkertijd schudde de psychiatrie in de jaren 60 en 70 op zijn grondvesten: het was de tijd van de richtingenstrijd en anti-psychiatrie die begin jaren 70 met Foudraine ook Nederland bereikte ${ }^{29}$. De toepassing van het medische model in de psychiatrie werd op de schop genomen, een model waarin psychiatrische ziektebeelden werden opgevat als uitingen van stoornissen van individuele patiënten. De anti-psychiatrie rekende hiermee af door te wijzen op de context (inclusief de psychiater zelf) waarin psychiatrische beelden zich ontwikkelden. In deze opvatting kunnen geestesziekten gezonde reacties zijn op een ongezonde omgeving (het biopsychosociale model). De anti-psychiatrie heeft na de jaren 70 sterk aan belang ingeboet maar heeft wel een geweldige impuls gegeven aan een ingrijpende restauratie van de DSM. De DSM-III werd namelijk op een totaal andere leest geschoeid dan voorheen. Mede onder druk van de wetenschap poogde men in de loop van de jaren 70 
een betrouwbaar en valide diagnostisch systeem te ontwikkelen dat het wetenschappelijk prestige van het vakgebied moest opvijzelen ${ }^{30}$. Had in de DSM-II de diagnose nog een zeer beperkte rol, in de nieuwe DSM-III vormden de psychiatrische diagnosen het leidende principe. Dat was een markante breuk met het verleden. In bijzonder korte tijd werd met dit nieuwe classificatie systeem een enorme paradigma shift tot stand gebracht. Met de DSM-III werd in de psychiatrie namelijk een classificatie systeem geïntroduceerd dat gebaseerd was op het diagnostisch model van de geneeskunde, waar de diagnose de basis is van de medische praktijk en het medisch onderzoek. Met deze introductie sloeg de psychiatrie twee vliegen in 1 klap: 1. De paradigma strijd kon worden geneutraliseerd want de DSM werd gebaseerd op symptoom diagnostiek en liet zich niet uit over de oorzaken van ziekte, en al zeker niet over de context. Daarmee werd de anti-psychiatrie de wind uit de zeilen genomen. 2. Door de mogelijkheid wel/geen ziekte via "harde "metingen" te objectiveren (het tellen van het aantal symptomen), kon het kwantitatieve wetenschappelijk onderzoek in de psychiatrie een hoge vlucht nemen. Overigens zijn er ook zorgen over het doorschieten van deze ontwikkeling, die er immers voor zorgde dat de neiging om psychische problemen in hun sociale context te plaatsen, werd geminimaliseerd. Dit deed nog in 2008 de toenmalige voorzitter van de APA verzuchten dat "psychiatrists have allowed the biopsychosocial model to become the biobiobio model". In de afgelopen decennia is het \% psychiatrische stoornissen met meer dan 300\% toegenomen (van 106 in de DSM-I naar 365 in de DSM-IV-TR). Het classificatie systeem is veel gedifferentieerder geworden (dyslectie, autisme, adhd, asperger). Allerlei problemen kwamen dus onder de aandacht van de psychiatrie, die dat eerder niet waren en die door hun specifieke omschrijving concreet meetbaar zijn geworden. Daarmee werden psychiatrische ziektebeelden niet alleen toegankelijk voor evidence base onderzoek, maar ook voor onderzoek door de farmaceutische industrie. Ook verzekeraars waren blij met vergroting van de "evidence base" van de psychiatrie en konden zij hun vergoedingen voor psychiatrische hulp beperken tot de effectief gebleken behandelingen.

De psychiatrie kreeg met de ontwikkeling van de DSM-III dus steeds meer "grip" op de haar aangeboden problemen. Voor veel problemen kwam een omschreven set van diagnostische criteria beschikbaar. In deze periode heeft de psychiatrie zich als medische discipline vervreemd van de somatisch specialismen, waardoor er in de huidige zorg een 
scheiding tussen de psychiatrische en somatische gezondheidszorg tot stand kwam³1. Ondanks alle successen bleef er ook veel kritiek op de DSM komen over de validiteit van de diagnostiek en het gebruik van een restcategorie voor stoornissen die niet aan de criteria voor de omschreven diagnoses voldeden. Zo heeft een frequent voorkomend maar lastig diagnostisch probleem als surmenage geen plek gekregen in de DSM-IV-TR. Ook kwam er kritiek op de psychiatrisering van psychosociale problemen en de toepassing van het medisch model.

Het kan niet anders of deze ontwikkeling is ook van invloed geweest op de diagnostiek van psychische problemen in de eerste lijn en de wijze waarop hulpverleners daarmee omsprongen. Daarom zal ik de drie belangrijke psychische problemen ook bij chronisch zieken in de eerste lijn bij de kop pakken: depressie, angst en somatisatie en nagaan in hoeverre hier iets van het vigerende "psychiatrisch paradigma" is terug te vinden.

\section{Ontwikkelingen in de psychiatrie en de zorg voor psychische problemen in de eerste lijn}

In Nederland werd de huisartsgeneeskunde in de tijd van de antipsychiatrie begin jaren 70 als wetenschappelijke discipline op de kaart gezet met de komst van afdelingen huisartsgeneeskunde aan de universiteiten en de beroepsopleidingen. Het is niet zo verrassend dat de antipsychiatrie in de huisartsgeneeskunde een warm onthaal kreeg. Met de definitie van huisartsenzorg op de Woudschoten conferentie werd eind jaren 50 al de integrale huisartsgeneeskunde gepropageerd met een duidelijk accent op contextgeneeskunde, gezinsgeneeskunde en een tweesporen benadering die stonden voor een gelijktijdige aanpak van psychosociale en lichamelijke problemen waar nodig. Op de Woudschoten conferentie werd huisartsgeneeskunde gedefinieerd als "het aanvaarden der verantwoordelijkheid voor een continue, integrale en persoonlijke zorg voor de gezondheid van de zich aan hem toevertrouwende individuele mensen en gezinnen"32. Deze definitie hield geruime tijd stand en overleefde de paradigma discussie die ook in de Nederlandse huisartsgeneeskunde eind jaren 70 losbarstte ${ }^{33}$. Ook de huisartsgeneeskunde als jongste loot aan de universitaire geneeskundige stam moest zich, net als de psychiatrie, verdedigen in een universitair klimaat dat gedomineerd werd door de preklinische en specialistische vakken, veelal met een lange wetenschappelijke 
traditie. Evenals in de psychiatrie werd er een sterke behoefte gevoeld om zich wetenschappelijk te bewijzen en ook die behoefte vormde een belangrijke impuls tot de ontwikkeling van een classificatie systeem dat toegang moest verschaffen tot de evidence based medicine. Uiteindelijk leidde dit tot de internationaal geaccepteerde International Classification of Primary Care (ICPC) 34 .

De vraag is nu of we in de ICPC iets terug zien van de ontwikkelingen in de psychiatrie. Binnen de ICPC is een apart hoofdstuk opgenomen voor psychische problemen (hoofdstuk P). Daarin treffen we angst en depressie aan, naast andere beelden waarvan verschillende voor een eerste lijnhulpverlener lijn betrekkelijk zeldzaam zijn, zoals psychose, hysterie of schizofrenie. Somatisatie ontbreekt in het rijtje. In de ICPC thesaurus zijn dus geen diagnostische criteria terug te vinden, daarvoor moeten we terug naar de NHG standaarden.

\section{Depressie}

De diagnostische criteria voor depressie in de standaard depressieve stoornis zijn geënt op de DSM-IV-TR. Er is sprake van een depressiestoornis als gedurende ten minste twee weken bijna dagelijks vijf of meer van 9 symptomen, waarvan ten minste hetzij sprake moet zijn van duidelijke vermindering van interesse of plezier in bijna alle activiteiten, hetzij een depressieve stemming gedurende het grootste deel van de dag; verder dient te worden doorgevraagd naar andere symptomen voor psychisch lijden zoals suïcidale gedachten, alcoholgebruik, ingrijpende levensgebeurtenissen en lijdensdruk van de patiënt. Genoemde symptomen en het scoringsalgoritme vinden we terug in de huidige versie van de psychiatrische classificatie, namelijk DSM-IV-TR35.

\section{Angst}

Angststoornissen worden, evenals in de DSM-IV-TR, onderverdeeld in paniekstoornis, agorafobie, specifieke fobie, sociale fobie, obsessieve compulsieve stoornis, posttraumatische stressstoornis en gegeneraliseerde angststoornis. De diagnostiek van deze verschillende varianten wordt in de standaard niet verder uitgediept via het tellen van aanwezige symptomen zoals bij depressie. Wel moet worden doorgevraagd naar belemmeringen in het dagelijks leven. De invloed van de DSM is zichtbaar in de indeling in typen angststoornissen. Verder wordt in deze standaard ook ingegaan op mogelijk andere gerelateerde psychische problematiek waaronder: Somatisatiestoornis: "chronische, 
medisch onverklaarde lichamelijke klachten waarbij niet zozeer angst op de voorgrond staat, als wel een ervaren gebrek aan erkenning van het lichamelijke ziek zijn. Patiënten voelen zich niet serieus genomen omdat de dokter geen afwijking kan vinden" 36 .

\section{Somatisatie}

Uiteraard hebben ook chronisch zieken vaak lichamelijke klachten. In de psychiatrie worden onder het hoofdstuk somatoforme stoornissen verschillende varianten onderscheiden (zoals conversie, hypochondrie, pijnstoornis en ook somatisatie stoornis) met ieder een eigen combinatie van diagnostische kenmerken. De somatisatie stoornis wordt omschreven als een aandoening met een voorgeschiedenis met vele lichamelijke klachten, beginnend vóór het zoste jaar die geleid hebben tot significante beperkingen in het sociale en beroepsmatige functioneren of functioneren op andere belangrijke terreinen. Vervolgens worden nog een aantal criteria opgesomd met o.m.: "na adequaat onderzoek is geen van de symptomen toe te schrijven aan een bekende somatische aandoening of aan het directe effect van een middel"37. Als er wel een somatische aandoening is, dan zijn de klachten of de daaruit voortvloeiende beperkingen ernstiger dan verwacht mocht worden op grond van anamnese of aanvullend onderzoek. Dit betekent dus dat ook iemand met een fysieke chronische aandoening de diagnose somatisatie stoornis kan krijgen. Wel lijkt het voor de psychiater lastig om te bepalen of aan de lichamelijke klachten van patiënten nu geheel of ten dele een organisch substraat ten grondslag ligt en zal ter uitsluiting hiervan over het algemeen de hulp van een somatisch georiënteerde specialist nodig zijn. Een somatisatie stoornis is volgens de DSM-IV-TR dus een ernstige psychiatrische stoornis met een hoge lijdenslast. In de eerste lijn zullen deze stoornissen veelal minder ernstig zijn en in lichtere vormen vaker en in grotere diversiteit voorkomen.

Het begrip Somatisatie heeft in de eerste lijn een wat onduidelijke ontwikkeling doorgemaakt. Het inmiddels verouderde begrip "nerveus functionele klachten" lijkt verwant, maar roept het bezwaar op dat het ontbreken van een somatische verklaring onmiddellijk de aandacht verlegd naar psychosociale oorzaken en dat is te makkelijk, want er zijn vele klachten waarvoor in de eerste lijn bij het gebruikelijke diagnostisch instrumentarium geen oorzaken gevonden kunnen worden, hetgeen natuurlijk nog niet wil zeggen dat die er ook niet zijn. Dit diagnostisch label veroorzaakt dan ook bij veel patiënten onbegrip omdat hiervan 
de suggestie uitgaat dat de patiënt niets mankeert. Veel patiënten met deze klachten laten het er niet bij zitten en eisen meer onderzoek ter bevestiging van een fysiek probleem. Dat het etiket NF wordt opgeplakt komt dus mede doordat de arts een proces uitlokt dat tot het etiket leidt ${ }^{38}$. De medicaliserende rol van de arts bij somatiserende patiënten vormde in de jaren 70 de opmaat voor preventie van somatische fixatie. Vroeg in mijn carrière maakte de Nijmeegse school al furore door op dit probleem te wijzen en daarvoor een theorie over somatische fixatie te ontwikkelen. Somatische fixatie te definiëren als: een proces van voortdurend exclusief somatisch omgaan met en reageren op ziekte, onlustgevoelens, klachten of problemen, door hen zelf, mensen uit hun omgeving of hulpverleners met als gevolg verafhankelijking en het risico vast te lopen in het medisch kanaa 39 . Opvallend aan deze definitie is het accent op het proces en de rol van de deelnemers aan dat proces. Er is niet alleen een rol weggelegd voor de patiënt, maar ook voor de sociale omgeving en belangrijker nog de hulpverlener. De nadruk ligt hier op het biopsychosociale model. Aandacht voor de fysieke gezondheid is vanzelfsprekend, maar eenzijdige aandacht kan ook bij chronisch zieken een proces van somatische fixatie bevorderen. Dat leidt tot onnodige afhankelijkheid van zorg en oplossingen voor problemen in het dagelijks leven raken op de achtergrond. Het vormde (als uitvloeisel van de biopsychosociale benadering) een helder verklaringsmodel voor de bijdrage van artsen en m.n. huisartsen, aan het vastlopen van mensen in het medisch kanaal. Toch was de theorie van preventie van somatische fixatie niet zo'n lang leven beschoren. Hoewel verschillende elementen van de theorie een vaste plek in de huisartsenopleiding kregen, verdween het begrip somatische fixatie uit het vocabulaire, waarschijnlijk omdat de benadering te weinig evidence based werd geacht. Vermoedelijk onder invloed van de ontwikkelingen in de psychiatrie werd teruggevallen op het begrip somatisatie. Nu ging het weer om een stoornis van de patiënt, te herkennen aan omschreven symptomen zonder de beïnvloedende factoren bij dit geheel te betrekken (medisch model). Somatisatie blijft de gemoederen terecht bezig houden, want het is een belangrijk probleem voor vele hulpverleners dat nog steeds geen bevredigende oplossing heeft. Dit leidt recent tot een nieuwe poging tot definitie, nu in een Multi-disciplinaire richtlijn. In de voorbereidingsgroep zitten alle disciplines die met het probleem te maken kunnen krijgen. In de conceptrichtlijn is te lezen dat de groep duidelijk afstand neemt van de psychiatrische diagnosegroep somatoforme stoornissen ${ }^{40}$. Zoals hiervoor vastgesteld gaat het in de DSM om hardnekkige en ernstige 
psychiatrische diagnosen, die in de eerste lijn relatief weinig gezien worden. Ook qua titulatuur wordt afscheid genomen van de DSM, want het probleem van niet te verklaren lichamelijk klachten wordt omgedoopt tot "somatisch onvoldoende verklaarde lichamelijke klachten"of wel SOLK. Als voorbeelden worden clusters van symptomen genoemd zoals prikkelbare darm syndroom, chronisch vermoeidheidssyndroom of fribromyalgie. Patiënten met SOLK hebben grote lijdensdruk, voelen zich ongezond, ervaren onrust en weinig kwaliteit van leven, hebben belemmeringen en verzuimen relatief veel. Ook hier wordt vastgesteld dat bij deze patiënten de arts patiënt communicatie vaker onder druk staat, omdat patiënten andere ideeën over de oorzaak van de klachten hebben dan de hulpverlener. Deze kan die klachten echter niet weerleggen, met vaak strijd met als inzet wie er gelijk heeft, tot gevolg. Wee de arts bij wiens patiënt uiteindelijk toch een afwijking gevonden wordt, terwijl hij steeds heeft volgehouden dat er somatisch niets aan de hand is. Hij/zij heeft de strijd definitief verloren.

Het onvermogen om voor lichamelijke klachten een lichamelijke oorzaak te benoemen, leidt bij de professional gemakkelijk tot de conclusie dat de klachten dan wel een psychische oorzaak moeten hebben, maar patiënten attribueren hun klachten aan een lichamelijke oorzaak. Bij iemand met een chronische aandoening ligt dat nog veel complexer. Immers bij iemand met een lichamelijke ziekte zijn diens klachten goed verklaarbaar op grond van de chronische ziekte en het deel dat er niet door verklaard wordt, is heel lastig af te bakenen. Bij bestaande risico's op complicaties is het bovendien riskant om symptomen als niet behorende bij de ziekte op te vatten. Dit leidt begrijpelijkerwijs tot defensief handelen (meer medisch handelen ter uitsluiting of vermindering van klachten). In de conceptrichtlijn SOLK zien we overigens (nog) niets terug over SOLK bij chronisch zieken. De auteurs komen tot de conclusie dat voor SOLK het biopsychosociale model het meest geschikt is, maar alle opmerkingen over het gevaar van relatiestrijd ten spijt, de rol van de hulpverlening komt hierbij (nog) niet in beeld. Echter de expliciete keuze voor het biopsychosociale model luidt een belangrijke ommekeer in na een periode waarin de psychiatrie (met het medisch model als uitgangspunt) haar invloed liet gelden op de ingeschatte ernst en aard van psychische problemen in de eerste lijn. 
We zien vanaf de jaren 80 een duidelijke invloed van de psychiatrie op de diagnostiek van psychische klachten in de eerste lijn. De DSM voorzag in een geweldige behoefte, want nu kon ook in de eerste lijn "harde" diagnostiek bij psychische klachten worden bedreven. Tegelijkertijd werd met de adoptie van de DSM rationale ook de ernst en de aard van het psychiatrisch morbiditeitspectrum geprojecteerd op dat van de eerste lijn, waardoor een vertekend beeld ontstaat van ernst en mogelijk ook de aard van de psychische problemen in de eerste lijn ${ }^{41}$. Wellicht schrijven huisartsen om die reden bij steeds lichtere depressieve klachten toch psychofarmaca voor, veelal zonder psychotherapie ${ }^{42,43}$. De invloed van de psychiatrie lijkt echter tanend want bij de ontwikkeling van SOLK bestaat een duidelijke aarzeling om aan te sluiten bij de DSM-IV-TR en wordt een meer huisartsgeneeskundige benadering nagestreefd die meer tegemoet moet komen aan de ernst en de aard van somatisatie problemen in de eerste lijn. Hoewel wordt vastgesteld dat voor SOLK het beste het biopsychosociale model gevolgd kan worden en bij SOLK patiënten de artspatiënt relatie vaak onder druk staat, wordt nog niet geconcludeerd dat de hulpverlener zo nu en dan wel eens een belangrijke invloed op het hulpverleningsproces zou kunnen hebben. In de standaarden over psychische problemen vinden we voorts weinig of niets terug over psychische problemen bij chronisch zieken. Zoals er in de specialistische geneeskunde in de periode van de anti-psychiatrie een duidelijke scheiding tussen de psychiatrie en de somatische gezondheidszorg tot stand kwam, zo zat er in de ontwikkeling van de NHG standaarden teveel het cartesiaanse onderscheid tussen lichamelijke en psychische klachten ingebakken. We zien daar nu een kentering in, getuige de aanpak van SOLK, en ook in het buitenland zien we dat de door het Engelse National Institute for Clinical Excellence (NICE; ontwikkelt ondermeer richtlijnen) herziene standaard depressie nu expliciet de richtlijn bevat dat rekening moet worden gehouden met de aanwezigheid van een fysieke chronische ziekte ${ }^{44}$. Dat zijn goede ontwikkelingen. Voor de zorg voor chronisch zieken geldt echter ook het omgekeerde: in de richtlijnen voor chronische aandoeningen moet consequent aandacht komen voor psychische problemen.

\section{De invloed van de marktwerking}

We bespraken al dat de farmaceutische industrie en zorg verzekeraars blij waren met de ontwikkeling van de DSM. Het maakte de psychiatrische zorg toegankelijk voor evidence based medicine en 
dat vergemakkelijkt het maken van keuzes in de zorg of het bepalen van onderzoekprioriteiten. Het marktdenken beheerst vanaf de jaren 80 het denken van politici en heeft daarmee een geweldige invloed gehad op alle sectoren en instituties in de samenleving. Een van de kernproblemen daarbij is dat de overheid/politiek met het oog op deregulering en doelmatigheidsvergroting een proces van terugtreden uit de verzorgingsstaat in gang heeft gezet en daardoor invloed heeft afgestaan aan de markt. Tegelijkertijd behield de overheid natuurlijk wel de verantwoordelijkheid voor beheersing van de kosten en de kwaliteit. Zorgpartijen werd daarom een verantwoordingsplicht opgelegd. Er moet verantwoording afgelegd worden aan de overheid over kwaliteit en kosten van de geleverde diensten. En dat wringt want vrije markt en controle zijn elkaars tegenpolen. Die verantwoordingsplicht heeft een grote bureaucratische rompslomp op gang gebracht van controle en evaluatie mechanismen. Deze trekjes van het neoliberale gedachten zien we ook terug in de gezondheidszorg en het onderwijs. De vraag is in hoeverre het marktdenken mogelijk ook de kwaliteit van het onderwijs en de gezondheidszorg ten aanzien van de zorg voor chronisch zieken heeft beïnvloed.

\section{Het universitaire onderwijs/onderzoek}

Begin 2008 werden we opgeschrikt door de commissie Dijsselbloem die met een ontluisterende hoofdconclusie kwam over het Nederlandse onderwijs: "De overheid heeft haar kerntaak, het zeker stellen van de kwaliteit van het onderwijs, de afgelopen jaren ernstig verwaarloosd"45. Wat insiders al veel langer wisten, werd nu vanuit de politiek zelf vastgesteld; we hebben niet alleen een financiële crisis maar ook een onderwijscrisis. De commissie concludeert o.m. dat onderwijsvernieuwingen niet werden gedreven door wetenschappelijk onderzoek, maar door het streven naar efficiency verbetering en bezuiniging. In de vermarkting van het onderwijs springt vooral één basisprincipe eruit en dat is de output financiering ${ }^{46}$. Volgens dit basisprincipe wordt een onderwijsinstelling betaald op grond van afgeleverde studiepunten en diploma's. Dit is op te vatten als een perverse prikkel. Immers een onderwijsinstelling kijkt wel uit, voordat zij een student laat afvallen want dat wordt meteen in de portemonnee gevoeld. Dat leidt weer tot verdunning van kwaliteit want ook de zwakkere broeders moeten zoveel mogelijk het profijtelijke diploma krijgen. 
Selecteren op kwaliteit is dan eigenlijk al niet meer mogelijk, want dat betekent uitval. Essentieel in de filosofie van het neoliberalisme is dat het de mens opvat als een "homo economicus". In dit vocabulaire wordt het geven en ontvangen van onderwijs gezien als ruilhandel. De student koopt zijn studie- punten en diploma in. In dit marktdenken passen ook de reclamecampagnes die universiteiten ondernemen om studenten naar de universiteit te lokken en met een bontgeschakeerd aanbod van nieuwe opleidingen de markt van studenten te veroveren. Studenten hebben grote invloed op de inhoud van het onderwijs, want de klant is koning. Een opleiding met weinig studenten is in dit denken een kort leven beschoren.

Hoe ligt dat nu bij geneeskunde? Deze opleiding heeft al sinds jaar en dag een numerus fixus en dat betekent dat er meer vraag naar geneeskundig onderwijs is dan aanbod. Dus reclamecampagnes om studenten te lokken zijn hier eigenlijk niet nodig. Toch zijn ook hier duidelijke kenmerken van marktdenken zichtbaar. Ook in het medisch curriculum bepalen onderwijspunten en diploma's de inkomsten en ook hier zien we dat soms een doorslaggevend belang wordt gehecht aan het oordeel van studenten over de inhoud van het onderwijs. Dat oordeel is des te positiever naarmate de inhoud een hoger amusementsgehalte heeft. Uiteraard spreekt in dit verband een open hartoperatie meer tot de verbeelding van studenten dan de ervaren problemen waartegen chronisch zieken in het dagelijks leven aanlopen. We zien in de opleiding dan ook weinig gerichte aandacht voor beperkingen van chronische ziekten, de problemen die patiënten daarmee in het dagelijks leven kunnen hebben en hoe daar als hulpverlener mee om te gaan. Vaardigheden op dit terrein zijn ook lastig meetbaar en toetsbaar en incompetenties op dit terrein leiden niet zichtbaar tot calamiteiten.

Maar er speelt mogelijk ook nog een andere factor: De raamplannen geneeskunde vragen al vanaf 1990 meer aandacht voor chronisch zieken in het medisch curriculum. Veel is sindsdien bereikt met een eerder en intensiever contact met chronische patiënten in een vroeger stadium van de opleiding. In de praktijk van het onderwijs is meer aandacht voor chronische ziekten, maar evenals dat bij de NHG standaarden zo nu en dan ook het geval is, komt hier nog te vaak het medisch denkmodel als leidend principe terug. Hierdoor gaat het in de opleiding primair om de diagnostiek en behandeling van stoornissen. De aandacht voor de beperkingen als gevolg van chronische ziekten en de wijze waarop patiënten, hun naasten en vooral ook hulpverleners hiermee omgaan, blijft daardoor te beperkt. Het zijn tegelijkertijd de aspecten waarop 
de vaardigheden van studenten lastig zijn te ontwikkelen en te meten. De marktwerking in het onderwijs vormt daarmee naar mijn mening bepaald geen extra prikkel voor verbetering van de kwaliteit van het onderwijs op dit gebied.

\section{De gezondheidszorg}

Begin 2006 werd de marktwerking in de gezondheidszorg een feit (WMG, ZvW, WMO en AWBZ). De effecten van die stelselwijziging zijn zo duidelijk, dat een gecontroleerde studie tamelijk overbodig is. De gemeentelijke aanbesteding-procedures bleken een ernstige bedreiging voor de kwaliteit van de reguliere huishoudelijke zorg. Ondertussen komen er nieuwe initiatieven van de grond die inspelen op nieuwe mogelijkheden, zowel ten goede zoals buurtzorg (menselijkheid in plaats van bureaucratie) of ten kwade zoals de wildgroei van nieuwe poli's (snotterpoli, de kortademigheid poli of overgangspoli). Hier wil ik mij beperken tot een drietal thema's waaraan goed te zien is hoe de stelselwijziging de zorg voor chronisch zieken heeft beïnvloed: de outputfinanciering, kwaliteitsmetingen en de tweedeling.

\section{De output meting}

Net als in het onderwijs heeft deverantwoordingsplicht van zorgverleners geleid tot bureaucratie en wel op tweeërlei gebied. In de eerste plaats werd het product gezondheidszorg herleid tot hapklare brokken, want er moest een kostprijs bepaald worden met behulp waarvan de geleverde productie geprijsd kon worden. Er kwam een systeem om de productie in kaart te brengen (Diagnose behandel combinaties, Zorgzwaarte pakketten en keten DBC's) waarin het aanbod van zorg gevangen zou moeten worden. Een diagnose behandelcombinatie omvat het geheel van diagnostische en therapeutische verrichtingen rond een bepaald gezondheidsprobleem van een patiënt van alle betrokken hulpverleners. Deze herleiding tot de kleinste elementen van de zorg heeft geleid tot een astronomisch aantal DBC's47. In een DBC wordt het handelen van zorgverleners zoveel mogelijk tot kwantificeerbare eenheden herleid. Alleen dan kan immers een kostprijs van dat handelen bepaald worden. Voor een aantal wezenlijke aspecten van de zorg is dat nog niet zo simpel. Denk bijvoorbeeld aan afstemming en overleg tussen betrokken hulpverleners, aandacht voor datgene wat patiënten met een ziekte bezig houdt, overleg met familie en in het algemeen aandacht, zoals in het geval van chronisch zieken heel vaak van belang is. De al genoemde keten DBC's voor de eerste lijn zijn pogingen om zogenaamde planbare zorg in de eerste lijn te herleiden tot meetbare onderdelen van het geheel van zorg door alle betrokken hulpverleners. We zagen dat in de 
keten DBC diabetes tot dusverre voornamelijk plaats is ingeruimd voor de fysieke aspecten van een chronische ziekte. De kosten, verbonden aan psychische problematiek, zijn niet constant maar uiterst variabel en er is al zeker geen vast of gemiddeld prijskaartje per handeling of patiënt te bepalen. Het leidt echter tot een ongewenste consequentie. In de kostprijs beperkt men zich tot het meetbare en laat daarmee bij de bepaling van de kostprijs een wezenlijk element in zorg voor chronisch zieken achterwege, $\mathrm{nl}$. aandacht voor de ziektelast van patiënten.

\section{Het meten van kwaliteit}

De verantwoordingsplicht houdt ook in dat hulpverleners de kwaliteit van hun zorg transparant maken. Patiënten moeten immers voor de beste kwaliteit kunnen kiezen. Ook deze plicht heeft tot grote bureaucratisering geleid. Over het bepalen van kwaliteit en de determinanten daarvan is bijna altijd discussie mogelijk is. Zelfs als het gaat om bijvoorbeeld de relatief hoge Nederlandse perinatale sterfte, blijft het lastig om de oorzaken daarvan vast te stellen. Ook hier geldt dat, net als bij de output registratie, professionals als geen ander in staat zijn om met strategisch gedrag de cijfers naar hun hand te zetten en daarmee voor het oog te voldoen aan de gestelde norm. Kwaliteit van de zorg in het primaire proces kan bijna altijd alleen bepaald worden door professionals zelf, maar als het gaat om communicatieve en bejegening aspecten geldt dat het zelfs voor professionals erg lastig is om de kwaliteit te bepalen, ook al omdat daarover tussen professionals verschil van mening bestaat. Dit terrein vormt daarom geen hapklare brok die goed definieerbaar en leent zich dus slecht voor het meten van de kwaliteit van zorg. De aandacht van hulpverleners voor mentale aspecten bij chronisch zieken komt er in de kwaliteitsmetingen dan ook tamelijk beroerd vanaf.

\section{De tweedeling}

Mensen uit de lagere sociaal-economische milieu's is in vergelijking met de beter bedeelden in onze samenleving, een aanzienlijk korter leven beschoren (6-8 jaar), zijn vaker en maken in geval van chronische ziekte een langere periode van ziekte door ${ }^{48}$. Ondertussen zullen de kosten in de zorg verder stijgen. Ook zal het basispakket in de toekomst verder wordt uitgekleed, de vrijwillige verzekering opgetuigd en het eigen risico verhoogd. De toegankelijkheid van de zorg voor de minder bedeelden in het algemeen en voor degenen met een chronische ziekte in het bijzonder zal dus verder verslechteren. In de filosofie van het neoliberale gedachtegoed heeft iedereen de mogelijkheid om zijn situatie positief te beïnvloeden. Als je dus een beroerde situatie terecht komt, heb je dat primair aan jezelf te danken (blaming the victim). ledereen is immers 
verantwoordelijk voor zijn eigen situatie. We zien dit principe ook terug in het voorstel van de RVZ om een gezonde leefstijl te belonen met een lagere zorgpremie 49 . Het appel op de eigen verantwoordelijkheid voor een gezonde leefstijl miskent dat mensen aan de onderkant van de samenleving minder grip op hun leven hebben dan de beter gesitueerden. In eigen onderzoek hebben we vastgesteld dat slechte leefgewoonten, maar ook de ervaren geringe grip op de eigen situatie samenhangt met sociaaleconomische gezondheidsverschillen ${ }^{50,51}$. De marktwerking zal de toegankelijkheid tot de zorg voor mensen uit de lagere sociaal economische milieus verminderen en daarmee de tweedeling in de zorg verder vergroten.

\section{De toekomst}

Hoewel de eindtermen van de medische opleiding dus wel degelijk zijn meegegroeid met de veranderingen in de zorgvraag en - behoefte, is de praktijk van het medisch onderwijs en de zorg voor chronisch zieken toch meer dan wenselijk, geënt gebleven op het medisch model, met name waar het het onderwijs over chronische ziekten betreft. We zagen verder dat in de NHG richtlijnen voor een aantal prevalente chronisch ziekten weinig systematische aandacht is ingeruimd voor problemen met beperkingen in het dagelijks leven. Toch zijn er in de NHG richtlijnen prima aanknopingspunten te vinden voor een uitbreiding in de richting van het biopsychosociale model. In elke NHG standaard voor een chronische ziekte kan eenvoudig en consequent een richtlijn voor doorvragen naar mogelijke ziektelast worden opgenomen.

De huisartsgeneeskunde lijkt zich langzaam maar zeker los te maken van de invloed van de psychiatrie en daarmee van het toepassen van de symptoomdiagnostiek van de DSM-IV-TR op problemen in de eerste lijn. Met name voor context gerelateerde gezondheidsproblemen wordt het medisch model steeds meer ontoereikend geacht en wordt ingezien dat hierbij de rol van de hulpverlener in het hulpverleningsproces niet buiten schot kan blijven. Wie zien dit reveil terug in de wijze waarop het denken over somatisatie zich de afgelopen jaren heeft ontwikkeld van denken in termen van stoornis tot contextgerelateerde problematiek waarin de hulpverlener, ten goede of ten kwade een cruciale rol speelt. Dit inzicht is ook terug te vinden in een onlangs bepleitte nieuwe a anpak van klachten van depressie. Er wordt gepleit voor een stepped care benadering zowel voor de diagnostiek van depressie als van de therapie. Essentieel is een terughoudende aanpak bij de diagnostiek en therapie met gebruik van de kennis van de huisarts van de context waarin patiënten al jaren functioneren en waarvan de huisarts zelf deel uitmaakt. Bij patiënten 
met psychische klachten wordt rekening gehouden met wat er in het dagelijks leven bij deze patiënten speelt. Via "watchfull waiting" zo wordt voorgesteld, kan worden nagegaan hoe het verder gaat en kunnen bij persistente klachten of verergering alsnog de diagnostische criteria worden toegepast en kan voor een invasievere aanpak gekozen worden ${ }^{52}$. Ook in eigen onderzoek is een dergelijke aanpak nagestreefd, maar dan toegepast op chronisch zieken met stemmingsproblemen. Daarbij werd nagegaan tegen welke problemen deze chronisch zieken in het dagelijks leven aanlopen als gevolg van hun ziekte. Het bleek dat aansluiting bij wat patiënten het meeste bezig houdt in verband met hun ziekte (namelijk beperkingen in het dagelijks leven), de stemmingsproblemen deed verminderen, zonder dat de kosten van de zorg hierdoor stegen. Zij leerden in de loop van tijd de stemmingsproblemen een betere plek te geven en functioneerden daardoor beter. Deze aanpak werd door deze patiënten bijzonder geapprecieerd53.

Veel psychosociale problemen van mensen met een chronische aandoening zijn een uiting van normale levensproblemen en een sombere stemming en onzekerheid over de toekomst zijn daarbij functioneel en behoeven vaak geen behandeling, zeker niet met psychofarmaca. Het medicaliseren van deze problemen levert immers afhankelijke mensen op die steeds minder in staat zijn de normale problemen van het leven het hoofd te bieden. Daarom is van belang dat patiënten geactiveerd worden tot zelfmanagers die in staat zijn waar mogelijk, de regie over hun leven in eigen hand te nemen en te houden. De losmaking van het psychiatrische gedachtegoed is daarom een bijzonder hoopgevend signaal in deze tijd van bureaucratisering en verzakelijking. Bijzondere aandacht is daarbij nodig voor mensen uit de lagere sociaal economische milieu's.

Er in de afgelopen jaren een grote evidence base opgebouwd voor zorg aan chronisch zieken volgens het biopsychosociale model. We weten inmiddels van chronisch zieken dat zij bij psychosociale problemen........:

- slechte opvolgers van het medisch regiem zijn

- een ongunstiger beloop van hun ziekte hebben

- een relatief hoge medische consumptie hebben

- minder deelnemen aan het sociale leven

- hoog psychofarmaca gebruik hebben

- sterk beïnvloed worden door de houding van hulpverleners

- zich beter begrepen voelen als ook wordt ingegaan op de gevolgen van hun ziekte voor het dagelijks functioneren

- met zelfmanagement ondersteuning meer grip krijgen op hun dagelijks functioneren 
De tijd is rijp om de richtlijnen voor chronisch zieken consequent uit te rusten met een gedetailleerdere en minder vrijblijvende passage over doorvragen naar beperkingen en last daarmee ${ }^{54}$. Zorgstandaarden, keten DBC's, de kwaliteit indicatoren en de vergoedingen van zorgverzekeraars zullen zeker volgen.

Maar de kern kan niet worden vastgelegd in richtlijnen, kan niet geregistreerd of gemeten worden maar komt voort uit de intrinsieke motivatie van hulpverleners. Daarbij gaat het om aandacht voor datgene wat patiënten werkelijk bezig houdt. In mijn inaugurale rede, zo'n 10 jaar geleden, had ik het over de spagaat waarin de hulpverlening zit tussen medisch-somatische zorg en de autonomie van de patiënt. Een spagaat is geen gemakkelijke houding voor wie daarin onvoldoende getraind is. Vandaag, een jaar of tien verder, weten we dat hulpverleners een cruciale rol spelen in hoe het patiënten in hun dagelijks leven vergaat. $\mathrm{Er}$ is meer dan voldoende kennis voor handen om die training ter hand te nemen en uit deze ongemakkelijke houding te komen. Met het oog op een toekomstbestendige zorg is dat geen overbodige luxe.

Dank u voor uw aandacht 
1. Metz JCM, Pels Rijcken-van Erp Taalman Kip EH,Brand-Valkenburg BWM van den. Raamplan 1994 artsopleiding. Eindtermen van de artsopleiding. Nijmegen: Universitair publikatiebureau KU, 1994.

2. Herwaarden CLA, Laan, RFJM, Leunissen RRM. Raamplan artsenopleiding 2009 , NFU Utrecht, 2009

3. Brouns M, Schade B, Vlaskamp L. Ouderenzorg in CBOG perspectief. CBOG, Utrecht 2010

4. Anonymus. Interview met Rien Meijerink, voorzitter Raad voor de Volksgezondheid en Zorg. Zorgvisie 2010; 9: 10-13

5. Eijk JThM van. Levensgebeurtenissen en ziekte [proefschrift]; Nijmegen 1979

6. Penninx BWJH, Kriegsman DMW, Eijk JThM van, Boeke AJP, Deeg DJH. Differential effects of social support on the course of chronic diseases: a criteria-based literature study. Families, Systems and Health 1996; 14: 223-44.

7. Djernes, JK: Prevalence and predictors of depression in populations of elderly: a review. Acta Psychiatr Scand 2006; 113: 372-87.

8. Van Gool C.H., Kempen G.I.J.M., Penninx B.W.J.H., Deeg D.J.H., Beekman A.T.F., Van Eijk J.Th.M. Impact of depression on disablement in late middle aged and older persons: results from the Longitudinal Aging Study Amsterdam. Social Science \& Medicine 2005 , $60,25-36$

9. Kriegsman DMW, Penninx BWJH, Eijk JThM van. A Criterion-Based Literature Survey of the Relationship between Family Support and Incidence and Course of Chronic Disease in the Elderly. Fam Syst Med 1995; 68: 13-39.

10. Penninx B.W.J.H. Social support in elderly people with chronic diseases: does it really help. Wageningen: Ponsen \& Looijen, 1996 (Proefschrift; Vrije Universiteit; Promotor: Prof. dr. J.Th.M. van Eijk; Co-promotores: ms Dr. D.J.H. Deeg and Dr. T.G. van Tilburg).

11. Finniss D, Kaptchuk TJ, Miller F, Benedetti F. Biological, clinical, and ethical advances of placebo effects [review]. Lancet 2010; 375: 686-95

12. Verheul W, Sanders A, Bensing J. The effects of physicians "affect-oriented communication style and raising expectations on analogue patients' anxiety, affect and expectancies. PEC 2010; 80: 300-6

13. Penninx BWJH, Dijck R van. Depressie en somatische comorbiditeit. Ned Tijdschr Geneesk 2010; 154:A1784

14. DiMatteo MR, Lepper HS, Croghan TW. Depression is a risk factor for noncompliance with medical treatment: meta-analysis of the effects of anxiety and depression on patient adherence. Arch Int Med 2000;160:2101-7.

15. NHG standaard COPD. [tweede herziening]. H en W 2007; 8: 362-79

16. NHG standaard Artritis Huisarts Wet 2009;52(9):439-53. Huisarts en Wetenschap, jaargang 2009, nummer 9:439-453

17. NHG standaard Astma bij volwassenen. H en W 2007; 11: 537-51

18. NHG standaard diabetes mellitus type 2 (2e herziening). H en W 2006; 3: 137-52

19. NHG standaard beleid na myocard infarct. H en W 2005; 5: 220-231

20. NHG standaard CVA. H en W 2004; 11: 509-520 
21. Zorgstandaarden in model; [ Anonymous] Rapport over het model voor zorgstandaarden bij chronisch zieken, coördinatie platvorm Zorgstandaarden, Den Haag ZonMw, februari 2010.

22. NDF zorgstandaard; Transparantie en kwaliteit van diabetes zorg voor mensen met diabetes type 2. NDF, Amersfoort 2007

23. Anonymous. Zorgstandaard COPD; Amersfoort, Long Alliantie Nederland, 2010.

24. Struijs JN, Til JT van en Baan CA. Experimenteren met de keten-dbc diabetes. De eerste zichtbare effecten. RIVM, Sector Volksgezondheid, Bilthoven 2009

25. Wagner EH, Austin BT, Von Korff M. Organizing care for patients with chronic illness. Milbank Quarterly1996;74(4):511-44

26. Anonymous. Toekomst Zorg Thuis. Nieuwe trends, nieuwe kansen. NPCF, Stoom, Vianen, 2010

27. Grob GN. Origins of DSM-I: a study in appearance and reality. Am J Psychiatry 1991; $148(4): 421-31$

28. Houts AC. J Clinical Psychol 2000. Fifty years of psychiatric nomenclature: reflections on the 1943 War Department Technical Bulletin, Medical 203; 56 (7) 935-67

29. Foudraine J. Wie is van hout? Een gang door de psychiatrie. Ambo/ Anthos 1971

30. Mayes R, Horwitz AV. DSM-III and the revolution in the classification of mental illness. J History of the behavioural Sciences 2005; 41: 249-67

31. Honig A. Mind the body [inaugurale rede], VU Amsterdam, 2010

32. Huygen FJA. Huygen FJA. NHG-quo vadis? Huisarts Wet 1959;2:187-91

33. Es JC van. Paradigma's van de huisartsgeneeskunde. H en W 1978; 21: 451-8

34. http://nhg.artsennet.nl/kenniscentrum/k_implementatie/k_automatisering/k_icpc.htm

35. NHG standaard depressieve stoornis. Huisarts en Wetenschap, jaargang 2003, nummer $11: 614-623$

36. NHG standaard angststoornis. Huisarts en Wetenschap, jaargang 2004, nummer 1:26-37

37. Anonymous. Beknopte handleiding bij de diagnostische criteria van de DSM-IV-TR (1ste druk). Swets en Zeitlinger, LIsse, 2001

38. Horst $\mathrm{H}$ van der. Nerveus-functionele klachten bestaan niet. H en W, 2003: 11:602

39. Eijk JThM van, Grol R, Huygen FJA, et al. The family doctor and the prevention of somatic fixation. Fam Systems Med 1983; 1: 5-15.

40. Anonymous. Concept Multidisciplinaire richtlijn Somatisch Onvoldoende verklaarde Lichamelijke klachten en Somatoforme stoornissen. Trimbos instituut, Houten, 2009

41. Lucassen P, Rijswijk E van, Weel BauMgarten E van, Dowrick CD. Making fewer depression diagnoses: beneficial for patients? Mental health in family Medicine 2008; 5:161-5

42. Spies T, Mokkink H, De Vries Robbe,PD, Grol R. GPs often prescribe antidepressants irrespective the severity of depression. H en W 2004; 47:364-7

43. Eijk JThM van, Bosma H, Jonkers CCM, Lamers F, Muijrers PEM. Prescribing Antidepressants en benzodiazepines in the Netherlands: Is chronic physical illness involved? Depression Research and Treatment 2010; Article ID 105931, 6 pages, doi:10.1155/2010/105931 
44. Pilling S, Anderson J, Goldberg D, Meader N, Taylor C. Depression in Adults, including those with a chronic physical health problem; Summary of the NICE guideline. BMJ 2009; 339: 1025-7

45. Dijsselbloem et al. Tijd voor onderwijs; Den Haag, 2008

46. Lorenz C (red). If you're so smart, why aren't you richt; Universiteit, Markt en Management. Amsterdam, Boom, 2008

47. Anonymous. Indeling productgroepen per diagnoseclassificatie. De Productstructuur DBC GGZ 2008. Utrecht juli 2007

48. Volksgezondheid Toekomst Verkenning, Nationaal Kompas Volksgezondheid. Bilthoven: RIVM, <http://www.nationaalkompas.nl> versie 3.22, 24 juni 2010.

49. RVZ, Zorg voor je gezondheid! Gedrag en gezondheid: de nieuwe ordening 2010, Raad voor de Volksgezondheid en Zorg: Den Haag.

50. Lynch JW, Kaplan GA, Salonen JT. Why do poor people behave poorly? Variation in adult health behaviours and psychosocial characteristics by stages of socioeconomic life course

51. Koster A, Bosma H, Kempen GIJM, Penninx BWJH, Beekman ATF, Deeg DJH, Eijk JThM van. Socio-economic differences in incident depression in older adults: The role of psychosocial factors, physical health, and behavioral factors. J Psychosom Res 2006; 61: 619-27

52. Weel-Baumgarten E van, Lucassen P, Hassink-Franke, Schers H. A different way of looking at depression. Clinical Practice 2010; 11: 1493-5

53. Lamers F, Jonkers CCM, Bosma H, Kempen GIJM, Meijer JAMJ, Penninx BWJH, Knottnerus JA, Eijk JThM van. A minimal psychological intervention in chronically ill elderly patients with depression: a randomised trial. Psychother \& Psychosom 2010; $79(4): 217-26$

54. Eijk JThM van, Terluin B. Aandacht voor psychosociale aspecten hoort ook bij de zorg voor chronisch zieken: maar hoe moet dat dan? [commentaar] H en W 2010; 53 (7): 356-57 